\title{
Pancreatic Panniculitis: A Rare Presentation Case
}

\section{Paniculite Pancreática: Forma de Apresentação Rara}

Eunice Vieira e Monteiro¹, Ana Munhoz¹, Cláudia Paiva², Paulo Aguiar Soares³

Corresponding author/Autor correspondente: Eunice Vieira e Monteiro [eunicevieiraemonteiro@gmail.com] Largo do Prof. Abel Salazar, 4099-001 Porto, Portugal ORCID iD: 0000-0002-7614-6263

KEYWORDS: Pancreatic Diseases/diagnosis; Panniculitis/diagnosis

PALAVRAS-CHAVE: Doenças do Pâncreas/diagnóstico; Paniculite/diagnóstico

A 46-year-old man with a personal history of kidney transplantation in 1994 for reflux nephropathy with chronic graft dysfunction.

Admitted with necrotizing pneumonia requiring VATS on 06/2019. He developed lower limb, nodular, erythematous, painful, non-pruritic, bilateral lesions (Fig. 1); biopsy revealed pancreatic panniculitis; he had elevation of serum amylase and lipase (9x upper normal level). ${ }^{1-5}$ No smoking or alcoholic habits.

Readmitted on 08/2019 with progression of the cutaneous lesions which improved with topical betamethasone (Fig. 2).

\begin{abstract}
Despite the absence of acute pancreatitis symptoms, he was placed with total parental nutrition and suspended cyclosporine and diuretics. Imagiological studies (ultrasonography, computed tomography scan, pancreatic echoendoscopy and PET scan) showed no alterations compatible with acute/chronic pancreatitis neither pancreatic carcinoma and the serum amylase and lipase decreased to values compatible with kidney disease. .,3,5 $^{2}$ The authors emphasize the originality of this case given the resolution of symptoms and no findings of pancreatitis nor pancreatic carcinoma. ${ }^{1,4,5}$
\end{abstract}

1. General Surgery Resident. Centro Hospitalar Universitário do Porto - General Surgery Service, Porto, Portugal. 2. Assistant at Extra-digestive Unit. Centro Hospitalar Universitário do Porto - General Surgery Service, Porto, Portugal. 3. Graduated Assistant at Hepatobiliopancreatic Unit of General Surgery Service and Liver and Pancreatic Transplant Program at Transplantation Department. Centro Hospitalar Universitário do Porto - General Surgery Service, Porto, Portugal. 


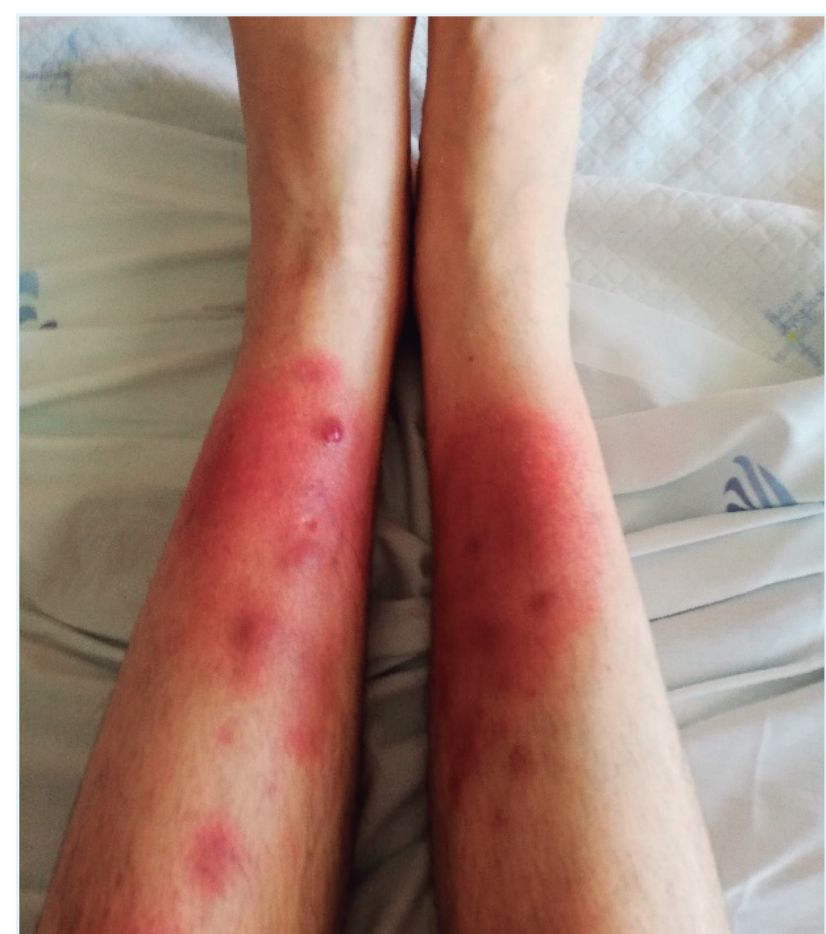

FIGURE 1. Pancreatic panniculitis in a kidney transplant patient with chronic graft dysfunction.

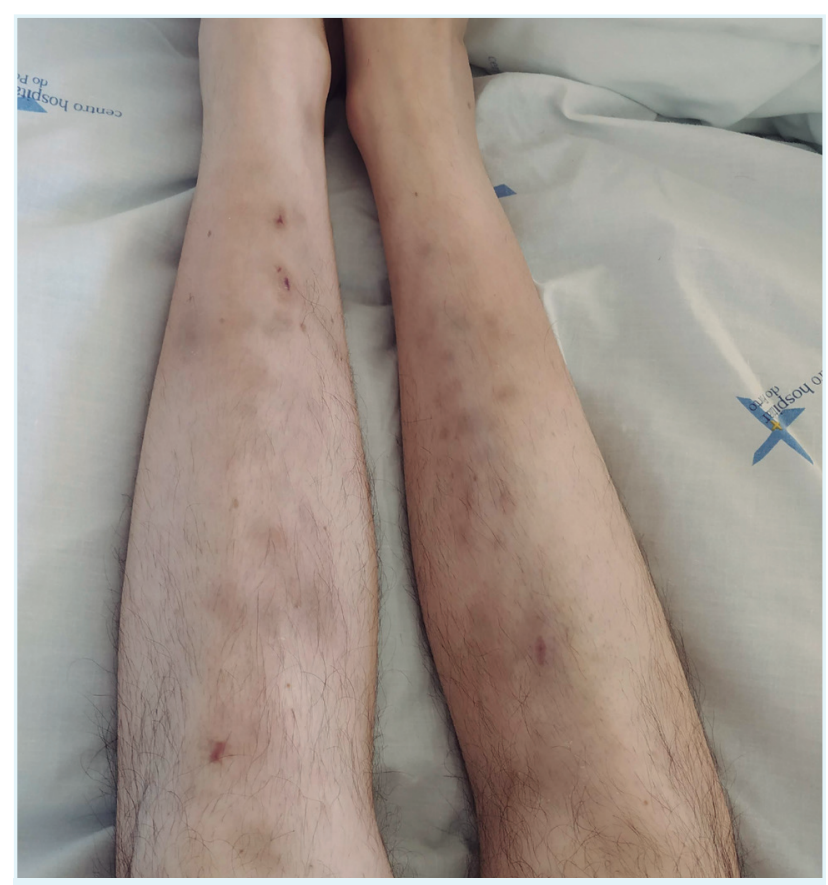

FIGURE 2. Improvement of skins lesions after treatment.
CONFLITOS DE INTERESSE: Os autores declaram não ter qualquer conflito de interesse na realização do presente trabalho.

FONTES DE FINANCIAMENTO: Não houve qualquer fonte de financiamento na realização do presente trabalho.

CONFIDENCIALIDADE DOS DADOS: Os autores declaram ter seguido os protocolos da sua instituição acerca da publicação dos dados de doentes.

CONSENTIMENTO: Consentimento do doente para publicação obtido.

PROVENIÊNCIA E REVISÃO POR PARES: Não comissionado; revisão externa por pares.

CONFLICTS OF INTEREST: The authors declare that they have no conflicts of interest.

FINANCIAL SUPPORT: This work has not received any contribution, grant or scholarship.

CONFIDENTIALITY OF DATA: The authors declare that they have followed the protocols of their work center on the publication of data from patients.

PATIENT CONSENT: Consent for publication was obtained.

PROVENANCE AND PEER REVIEW: Not commissioned; externally peer reviewed.

\section{REFERENCES}

1. Guanziroli E, Colombo A, Coggi A, Gianotti R, Marzano AV. Pancreatic panniculitis: The "bright" side of the moon in solid cancer patients. BMC Gastroenterol. 2018;18:1. doi: 10.1186/s12876-017-0727-1.

2. Souza FH, Siqueira EB, Mesquita L, Fabricio LZ, Tuon FF. Pancreatic panniculitis as the first manifestation of visceral disease - Case report. An Bras Dermatol. 2011;86(4 Suppl 1):S125-8.

3. Evans AC, Singhi AD, Zeh HJ, Bahary N, Brand RE. An unexpected etiology of pancreatic panniculitis: A Case Report. J Pancreat Cancer. 2017;3:1-4. doi: 10.1089/crpc.2016.0021.

4. Neves Z, Segura Ú, Valente A, Pacheco MH, Malhado J. Panniculitis - A Rare Manifestation of Acute Pancreatitis. GE Port J Gastroenterol. 2015;22:117-20.

5. Zhang MY, Tian B Le. Pancreatic panniculitis and solid pseudopapillary tumor of the pancreas: A case report. World J Clin Cases. 2018;6:1036-41. 